\title{
Road Damage Conditions Analysis Of Tanjung Api- Api - Gasing District Road Based On Surface Distress Index (Sdi) Method
}

\author{
R. Marpen ${ }^{1, *}$ A. Hasan ${ }^{1}$ AN. Sari ${ }^{1}$ HWS. Putra ${ }^{1}$ R. Pranoto ${ }^{1}$ \\ ${ }^{1}$ Jurusan Teknik Sipil, Politeknik Negeri Sriwijaya, Palembang Jl. Srijaya Negara Bukit Besar, Palembang, Sumatera \\ Selatan 30139 \\ *Corresponding author. Email: riomarpen@polsri.ac.id
}

\begin{abstract}
One of the potential roads in South Sumatra Province is the Tanjung Api-Api - Gasing road. So that good maintenance is needed so that community activities can run smoothly. In this study, the method used to evaluate the level of damage to the Tanjung Api-Api - Gasing road section is the Surface Distress Index (SDI) method. The purpose of this research is to carry out an inventory of current conditions and build a database or geodatabase for the Tanjung Api-api - Gasing district road. Based on the results of the field survey, the entire road width is $4 \mathrm{~m}$ and uses rigid pavement. Field survey observations, some field conditions are not good. Where there are still some segments that have a rough arrangement with a detached state. There are some fixes in the form of patches. On roads there is no decline that occurs. The results of the SDI analysis carried out can be concluded that there are 3 segments that are heavily damaged and 1 segment in moderate condition, while the other segments are still in good condition.
\end{abstract}

Keywords: SDI (Surface Distress Index), Rigid Pavement, Tanjung api-api Gasing.

\section{INTRODUCTION}

\subsection{Background}

South Sumatra is one of the areas that located in the southern part of Sumatra Island. One of South Sumatra districts is Banyuasin. Currently, the province of South Sumatra is experiencing rapid development, especially in the industry, tourism, education, public transportation and other public services sectors. To support this development, good transportation facilities are needed, especially roads. There are many potential roads that must be planned as well as possible.

One of the potential roads in South Sumatra Province is the Tanjung Api-Api - Gasing district road. The Tanjung Api-Api - Gasing distrit road is a residential road with a fairly high level of activity. Residents use the road as a means of connecting during their daily activities. The passing vehicles are not only small vehicles, but also heavy vehicles such as trucks. So that good maintenance is needed so that community activities can run smoothly.

In this study, the method used to evaluate the level of damage to the Tanjung Api-Api - Gasing district road is the Surface Distress Index (SDI) method. This method is takes into account the scale of road performance based on the results of observations made visually in the field. By using this method, it is hoped that later it can be used as input for related agencies to make improvements if necessary.

\subsection{Research Objectives}

The objectives of this study are:

1. To make an inventory of the current condition of Tanjung Api-api - Gasing district road.

2. To build a database or geodatabase for Tanjung Apiapi district - Gasing district road.

\subsection{Problem Statemant}

The problems in this research are:

1. There is limited information and data regarding the condition of district roads, especially the Tanjung Api-api - Gasing district road.

2. How to provide inventory data to build and update inventory data for the Tanjung Api-api Gasing district road.

\subsection{Problem boundary and Study Scope}

The problem boundaries and study scope in this study include:

1. The section that is the object of the making of this research is Tanjung Api-api - Gasing district 
$\operatorname{road}( \pm 1.2 \mathrm{~km})$

2. The data used in this study are survey and spatial data.

3. Development and data analysis is by using the ArcGIS application and the SDI method based on the IRMS (Indonesia Road Management System) used in PU Bina Marga.

\section{RESEARCH METHOD}

\subsection{Research Stages}

The steps in this research begin with conducting a preliminary study which includes: introduction to the study area, literature review, survey, identification of data and software used. From the preliminary study conducted, it is continued with the identification of the problem so that the background of the problem and the formulation of the problem can be prepared and the determination of the objectives of this research.

The research steps are shown in the following research flow chart:

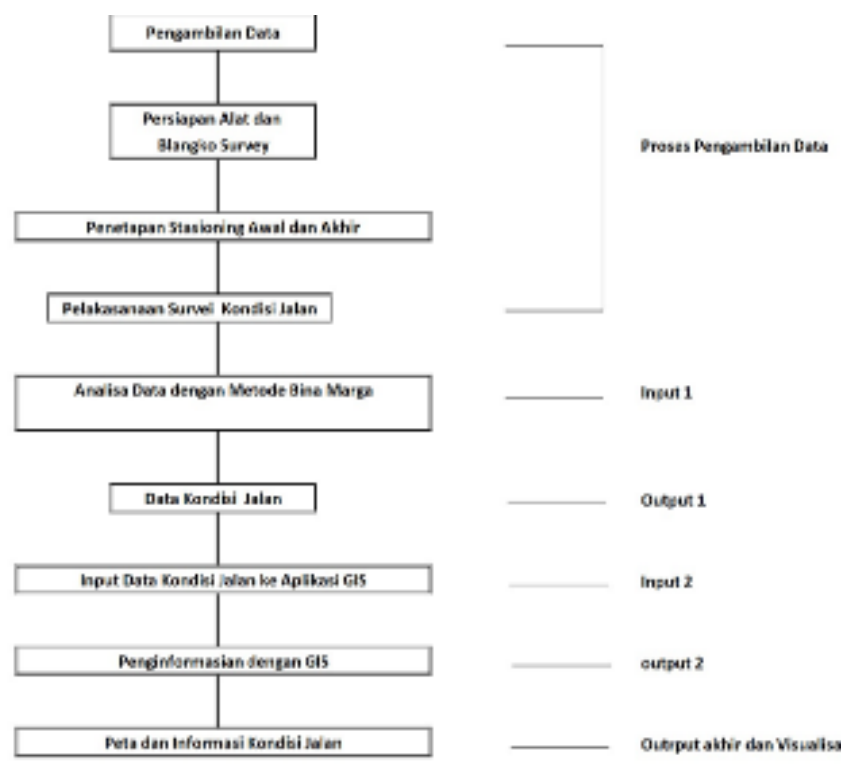

Figure 1 Research Flowchart

\subsection{Literature study}

Several sources of literature that can be used include abstracts of research results, indexes, reviews, journal reference books.

1. The abstract of the research results is a valuable source of reference because the abstract contains the essence of the research

2. The index provides book titles arranged according to the main description of each book but does not provide an abstract

3. Reviews contain writings that synthesize works or books that have been written in a certain period of time. The writing is arranged based on topic and content.
4. Journals contain writings in the same disciplines, for example management science in economics or informatics engineering in computer science.

5. Reference books contain general writings in certain disciplines.

\subsection{Data Collecting}

\subsubsection{Type of data}

The data obtained consists of:

1. Primary Data

2. Secondary Data

\subsubsection{Research Location}

This research was conducted in the Tanjung Apiapi - Gasing district road.

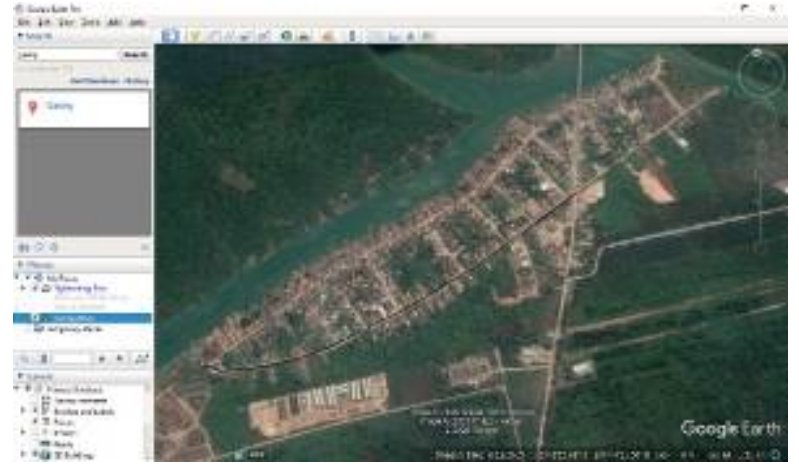

Figure 2 Research Location

\subsubsection{Data collection Survey for road inventory}

1. Preliminary Survey

2. Road Condition Survey

Stage of the survey is as follows.

1. The observer takes measurements with a measuring wheel and tape measure and then records the description of the measurement results.

2. Data from the results of road conditions will be entered into the prepared survey form.

3. Equipment and time

In this study, several tools were used to support the implementation of research in the field as follows.
a. Stationary
b. Length measuring device (meter) and roller meter.
c. Camera
d. GPS

4. Survey team

The team to carry out this survey consisted of 4 people who were divided according to the work of each surveyor. The survey was conducted from Sta. $0+000$ up to Sta. $1+200$.

5. Applications

Software as a tool used in analysing can be used Microsoft Excel program and ArcGIS application. 


\subsection{Geodatabase Creating}

The steps for creating a geodatabase are:

1 .

Convert

GPS tracking (* .gpx format) into shapefile (* .shp) format by using ArcGIS application.

2. Joint

excel data table road conditions to the ArcGIS application with shapefile format.

3.

data that has been inputted.

Editing

4. Analysing the data that has been inputted.

\subsection{Data analysis}

Data analysis is an integrated job after data is obtained, then collected to be recapitulated as needed and then is analysing by using the IRMS (Indonesia Road Management System) application and with the GIS (Geographic Information System) application.

The data obtained from the field are processed by calculating SDI based on the IRMS (Indonesia Road Management System) to determine the existing road conditions and the output of the IRMS application shows the road condition data. This output data is continued as input for data to the GIS (Geographic Information System) application.

The results of this analysis determine the accuracy of the program in providing information to the user. The final results of the analysis show the road conditions for road maintenance at Tanjung Api-api - Gasing district road.

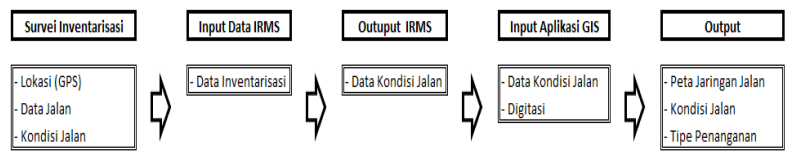

Figure 3 Data Analysis Flowchart

\section{RESULTS AND DISCUSSION}

\subsection{Road Geometric Data}

In conducting the survey, the road segment is divided into 11 segments (starting from STA 000 to STA 1.200), each segment is $100 \mathrm{~m}$. The measurement results obtained are geometric data (road width, roadside width, surface layer type) and road damage condition data. In general, the geometric section of Jalan Tanjung Api-api - Gasing along $\pm 1,200 \mathrm{~m}$ has a width of $4 \mathrm{~m}$ and does not have a roadside (roadside width $0 \mathrm{~m}$ ), while the surface layer of the road is rigid. The measurement data in the form of geometric roads are presented in Table 3.
Table 1. Geometric data Tanjung Api-api - Gasing district road

\begin{tabular}{|c|c|c|c|}
\hline$(\mathrm{STA})$ & $\begin{array}{c}\text { Road } \\
\text { Width } \\
(\mathrm{m})\end{array}$ & $\begin{array}{c}\text { Surface } \\
\text { coating type }\end{array}$ & Information \\
\hline $000-100$ & 4 & Rigid & Segmen I \\
\hline $100-200$ & 4 & Rigid & Segmen II \\
\hline $200-300$ & 4 & Rigid & Segmen III \\
\hline $300-400$ & 4 & Rigid & Segmen IV \\
\hline $400-500$ & 4 & Rigid & Segmen V \\
\hline $500-600$ & 4 & Rigid & Segmen VI \\
\hline $600-700$ & 4 & Rigid & Segmen VII \\
\hline $700-800$ & 4 & Rigid & Segmen VIII \\
\hline $800-900$ & 4 & Rigid & Segmen IX \\
\hline $900-1.000$ & 4 & Rigid & Segmen X \\
\hline $1.000-1.100$ & 4 & Rigid & Segmen XI \\
\hline $1.100-1.200$ & 4 & Rigid & Segmen XII \\
\hline
\end{tabular}

Based on the results of the field survey, the entire road width is $4 \mathrm{~m}$ and uses rigid pavement.

\subsection{Road Pavement Layer Conditions}

A visual survey of the pavement surface conditions was carried out for each lane divided by segments per $100 \mathrm{~m}$ in length, in each traffic direction. The pavement surface conditions observed were the composition, the percentage of degradation and the percentage of patching (Table 4).

Table 2. Observation Results of Pavement Surface Conditions

\begin{tabular}{|c|c|c|c|c|}
\hline \multirow{2}{*}{ STA } & \multicolumn{4}{|c|}{ Road Pavement Surface Assessment } \\
\cline { 2 - 5 } & composition & Conditions & degradation & Patching \\
\hline $\begin{array}{c}000- \\
100\end{array}$ & rough & unravel & Nothing & Nothing \\
\hline $\begin{array}{c}100- \\
200\end{array}$ & rough & Hancur & Nothing & $<10 \%$ area \\
\hline $\begin{array}{c}200- \\
300\end{array}$ & rough & unravel & Nothing & Nothing \\
\hline $\begin{array}{c}300- \\
400\end{array}$ & rough & unravel & Nothing & $<10 \%$ area \\
\hline $\begin{array}{c}400- \\
500\end{array}$ & rough & unravel & Nothing & Nothing \\
\hline $\begin{array}{c}500- \\
600\end{array}$ & good/tight & good & Nothing & Nothing \\
\hline $\begin{array}{c}600- \\
700\end{array}$ & good/tight & good & Nothing & Nothing \\
\hline $\begin{array}{c}700- \\
800\end{array}$ & good/tight & good & Nothing & Nothing \\
\hline $\begin{array}{c}800- \\
900\end{array}$ & good/tight & good & Nothing & Nothing \\
\hline $\begin{array}{c}900- \\
1.000\end{array}$ & good/tight & good & Nothing & Nothing \\
\hline $\begin{array}{c}1.000- \\
1.100\end{array}$ & rough & good & $<10 \%$ area & Nothing \\
\hline $\begin{array}{c}1.100- \\
1.200\end{array}$ & good/tight & good & Nothing & Nothing \\
\hline
\end{tabular}

Field survey observations, some field conditions are not good. Where there are still some segments that have a rough arrangement with a detached state. There are 
some fixes in the form of patches. On roads there is no decline that occurs.

\subsection{Road Crack Conditions}

Table 3. Observation Results of Cracks Conditions Jalan

\begin{tabular}{|c|c|c|c|c|}
\hline \multirow{2}{*}{ STA } & \multirow{2}{*}{$\begin{array}{c}\text { Lenght } \\
(\mathrm{m})\end{array}$} & \multicolumn{3}{|c|}{ Assessment of Road Cracks } \\
\cline { 3 - 5 } & Type & width & \% Area \\
\hline $000-100$ & 100 & 3 & 4 & 4 \\
\hline $100-200$ & 100 & 3 & 4 & 4 \\
\hline $200-300$ & 100 & 3 & 4 & 1 \\
\hline $300-400$ & 100 & 3 & 2 & 4 \\
\hline $400-500$ & 100 & 3 & 4 & 3 \\
\hline $500-600$ & 100 & 2 & 4 & 1 \\
\hline $600-700$ & 100 & 2 & 4 & 1 \\
\hline $700-800$ & 100 & 3 & 4 & 1 \\
\hline $800-900$ & 100 & 2 & 4 & 1 \\
\hline $900-1.000$ & 100 & 3 & 1 & 1 \\
\hline $1.000-1.100$ & 100 & 2 & 3 & 1 \\
\hline $1.100-1.200$ & 100 & 2 & 1 & 1 \\
\hline
\end{tabular}

\subsection{Other Damage Conditions}

Table 4. Observations of the number / size of holes, ruts, edge damage

\begin{tabular}{|c|c|c|c|c|c|}
\hline \multirow{3}{*}{ STA } & \multicolumn{5}{|c|}{ Other Damage Assessments } \\
\hline & \multirow{2}{*}{$\begin{array}{l}\text { Number } \\
\text { of Holes }\end{array}$} & \multirow{2}{*}{$\begin{array}{l}\text { Hole } \\
\text { Size }\end{array}$} & \multirow{2}{*}{ Rut } & \multicolumn{2}{|c|}{ Edge Damage } \\
\hline & & & & Right & Left \\
\hline $000-100$ & 4 & 4 & 1 & 1 & 2 \\
\hline $100-200$ & 4 & 5 & 1 & 1 & 3 \\
\hline $200-300$ & 1 & 1 & 1 & 1 & 1 \\
\hline $300-400$ & 4 & 4 & 1 & 1 & 3 \\
\hline $400-500$ & 3 & 2 & 1 & 1 & 1 \\
\hline $500-600$ & 1 & 1 & 1 & 1 & 1 \\
\hline $600-700$ & 1 & 1 & 1 & 1 & 1 \\
\hline $700-800$ & 1 & 1 & 1 & 1 & 1 \\
\hline $800-900$ & 1 & 1 & 1 & 1 & 1 \\
\hline $\begin{array}{l}900- \\
1.000\end{array}$ & 1 & 1 & 1 & 1 & 1 \\
\hline $1.000-1.100$ & 1 & 1 & 1 & 1 & 1 \\
\hline $1.100-1.200$ & 1 & 1 & 1 & 1 & 1 \\
\hline
\end{tabular}

\subsection{Conditions of Roadside and Drainage Channels}

Table 5. Observation results for side road and side drainage conditions

\begin{tabular}{|c|c|c|c|c|c|c|}
\hline $\begin{array}{c}\text { Roadside } \\
\text { Condition }\end{array}$ & \multicolumn{2}{|c|}{$\begin{array}{c}\text { Surface } \\
\text { Roadside }\end{array}$} & \multicolumn{2}{c|}{$\begin{array}{c}\text { Drainage } \\
\text { Conditions }\end{array}$} & $\begin{array}{c}\text { Slope } \\
\text { Damage }\end{array}$ & $\begin{array}{c}\text { Side } \\
\text { walk }\end{array}$ \\
\hline Both & Right & Left & Right & Left & Both & Both \\
\hline 2 & 4 & 4 & 2 & 2 & 1 & 1 \\
\hline 2 & 5 & 5 & 2 & 2 & 1 & 1 \\
\hline 2 & 4 & 3 & 3 & 3 & 1 & 1 \\
\hline 2 & 4 & 5 & 3 & 3 & 1 & 1 \\
\hline 2 & 3 & 4 & 1 & 3 & 1 & 1 \\
\hline 2 & 4 & 4 & 1 & 3 & 1 & 1 \\
\hline 2 & 4 & 4 & 1 & 3 & 1 & 1 \\
\hline 2 & 5 & 5 & 1 & 3 & 1 & 1 \\
\hline 1 & 1 & 1 & 1 & 3 & 1 & 1 \\
\hline 1 & 1 & 1 & 1 & 1 & 1 & 1 \\
\hline 1 & 1 & 1 & 1 & 1 & 1 & 1 \\
\hline 1 & 1 & 1 & 1 & 1 & 1 & 1 \\
\hline
\end{tabular}

\subsection{SDI Value Calculation}

Table 6. Calculation of SDI values and determining road conditions

\begin{tabular}{|c|c|c|}
\hline STA & $\begin{array}{c}\text { SDI } \\
\text { Value }\end{array}$ & $\begin{array}{c}\text { Description of } \\
\text { Road Conditions }\end{array}$ \\
\hline $000-100$ & 305 & $\begin{array}{c}\text { Heavily } \\
\text { damaged }\end{array}$ \\
\hline $100-200$ & 305 & $\begin{array}{c}\text { Heavily } \\
\text { damaged }\end{array}$ \\
\hline $200-300$ & 40 & Good \\
\hline $300-400$ & 265 & $\begin{array}{c}\text { Heavily } \\
\text { damaged }\end{array}$ \\
\hline $400-500$ & 85 & Moderate \\
\hline $500-600$ & 10 & Good \\
\hline $600-700$ & 40 & Good \\
\hline $700-800$ & 10 & Good \\
\hline $800-900$ & 10 & Good \\
\hline $900-1.000$ & 5 & Good \\
\hline $1.000-1.100$ & 5 & Good \\
\hline $1.100-1.200$ & 5 & Good \\
\hline
\end{tabular}

The results of the SDI analysis carried out can be concluded that there are 3 segments that are heavily damaged and 1 segment in moderate condition, while the other segments are still in good condition. 


\subsection{Discussion}

Based on tables from JBI and analysis on the LHR survey data, it was found that there were vehicles passing through the Tanjung Api-Api - Topping road that exceeded the maximum load of the road structure at the research location, namely 4 to 5 trucks per day which had an axle load of 6-8 tons when following the permitted weight.

If the traffic load is from the two approaches above, namely the traffic load based on ESAL calculations and the allowable axle load approach based on Government Regulation No. 55/2012 Article 57, traffic load does not appear to affect significantly due to the small amount of load. It can be believed that the damage to the pavement is more significantly affected by drainage factors as well as the lack of maintenance on the roads.

\subsection{Geomapping of Road Damage}

Based on the results of the discussion from the observations obtained input data which is then processed using the ArcGIS application to make Road Damage Geomapping. The results of data processing using ArcGIS to produce a road damage map can be seen in the image below.

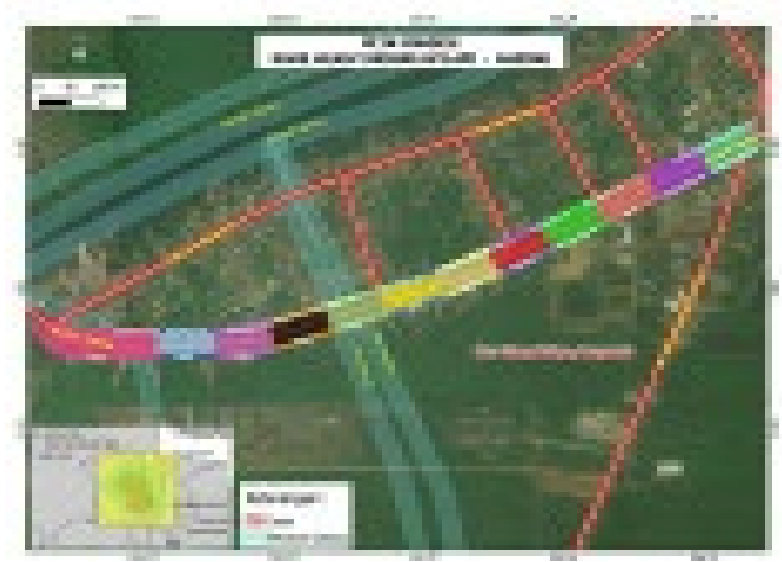

Figure 4 Roadmap of Road Damage

\section{CONCLUSION}

Based on SDI analysis, it can be concluded that there are 3 segments that are heavily damaged and 1 segment is in moderate condition, while the other sections are still in good condition. The cause of the damage was not only due to traffic but the lack of pavement and maintenance.

Tanjung Api-api - Jalan Gasing requires an upgrade to class III road which is based on Law no. 22/2009 concerning Road Traffic and Transportation Article 19 paragraph 2, the maximum vehicle that passes is 8 tons and immediate maintenance to avoid the possibility of serious damage. Future research will be better if analyzed with complete data including planning data and environmental conditions. To get more accurate results it would be better to use the Planning and As-Built Drawing data from road construction to determine the design age and capability of the road structure.

An overview of road conditions can be seen in the appendix, which is the result of digitizing using a GIS program to provide detailed information on each segment of the road under study.

\section{REFERENCES}

[1] Bolla, M. E. 2012, Perbandingan Metode Bina Marga Dan Metode Pci (Pavement Condition Index) Dalam Penilaian Kondisi Perkerasan Jalan), Universitas Nusa Cendana Kupang. www.puslit2.petra.ac.id, sitasi 21 September 2015

[2] Hermani, W. T., Setyawan, A. 2013. Kondisi Kemantapan Jalan Berdasarkan Beban Lalu Lintas dan Ketersediaan Dana Penanganan. Jurnal Teknik Sipil Magister Teknik Sipil Universitas Sebelas Maret, Vol. 1, No. 2. Hlm 1-6.

[3] Ichsan.,Dkk (2014), Studi Evaluasi Tingkat Kerusakan Permukaan Jalan Untuk Menentukan Jenis Penanganan Dengan Sistem Penilaian Menurut Bina Marga. (Studi Kasus: Ruas Jalan Bireuen Takengon), Universitas Syiah Kuala, Aceh.

[4] Kementerian Pekerjaan Umum. 2011. Peraturan Menteri Pekerjaan Umum Nomor 13 Tahun 2011 Tentang Tata Cara Pemeliharaan dan Penilikan Jalan. Jakarta

[5] Mahmood, M., Dkk (2013), A Fuzzy Logic Approach for Pavement Section Classification. Nottingham Trent University, Nottingham NGI 4BU, United Kingdom.

[6] Minarti, E., dkk (2014), Pengamatan Kerusakan Jalan dari Nilai Surface Distress Index (SDI) dan Nilai International Roughness Index. (Studi Kasus: Jalan Nasional

[7] Saputro, D. A., Djakfar L., Rachmansyah, A. Evaluasi Kondisi Jalan Dan Pengembangan Prioritas Penanganannya, (Studi Kasus di Kecamatan Kepanjen Kabupaten Malang), Jurnal: http://rekayasasipil.ub.ac.id, sitasi 17 September 2015

[8] Saputro, D.A. Perbandingan Evaluasi Tingkat Kerusakan Jalan Dengan Metode Bina Marga Dan Metode Paver (Studi Kasus : Kecamatan Kepanjen Kabupaten Malang Dan Sekitarnya), http://ejurnal.wisnuwardhana.ac.id , sitasi 17 September 2015 